\title{
POTRET NILAI NASIONALISME DALAM KUMPULAN CERPEN SEMUA UNTUK HINDIA KARYA IKSAKA BANU
}

\author{
Noveria Anggraeni Fiaji ${ }^{1}$, Fitrahayunitisna ${ }^{2}$, Prisca Kiki Wulandari ${ }^{3}$ \\ ${ }^{1}$ Fakultas Ilmu Sosial dan Ilmu Politik, Universitas Brawijaya \\ ${ }^{2}$ Fakultas Ilmu Budaya, Universitas Brawijaya \\ ${ }^{3}$ Fakultas Ilmu Sosial dan Ilmu Politik, Universitas Brawijaya \\ $\underline{\text { novafiaji@ub.ac.id }}{ }^{1}, \underline{\text { fitra_3006@ub.ac.id }}$, priscakiki@ub.ac.id ${ }^{3}$
}

\begin{abstract}
ABSTRAK
Sastra sebagai penghibur jiwa, sementara juga digunakan sebagai media untuk memotret peristiwa sosial di masa lampau termasuk masa colonial. Penelitian ini bertujuan menganalisis nilai-nilai nasionalisme dalam kumpulan cerpen Sетиa untuk Hindia karya Iksaka Banu. Penelitian menggunakan metode kualitatif-deskriptif dengan menggunakan pendekatan pascakolonial untuk menganalisis setiap cerita dalam kumpulan cerpen. Nilai-nilai nasionalisme yang dijadikan sebagai indikator adalah nasionalisme berdasarkan Pancasila. Adapun nasionalisme Pancasila terdiri dari: (1) nasionalisme religius, (2) nasionalisme kemanusiaan, (3) nasionalisme berkerakyatan, dan (4) nasionalisme berkeadilan. Hasil penelitian menjelaskan bahwa kumpulan cerpen Sетиа untuk Hindia memuat semua nilai-nilai nasionalisme yang dijadikan sebagai indikator penelitian. Nasionalisme yang paling banyak disorot dalam tiap-tiap cerpen yakni nasionalisme kemanusiaan. Walaupun dalam kondisi menjajah, sebagian orang Eropa memiliki empati kemanusiaan dengan warga pribumi dengan ia tetap mencintai tanah airnya. Hal sebaliknya juga dialami oleh warga pribumi, yang tidak menganggap semua orang Eropa musuh, mereka saling berkawan satu sama lain.
\end{abstract}

Kata Kunci: nilai; nasionalisme; Semua untuk Hindia;

\section{PENDAHULUAN}

Sastra memiliki hubungan yang berjalin kelindan dalam pembentukan bangsa. Dalam sejarah sastra, kerapkali sastra menjadi dokumen sejarah yang mampu memotret perjalanan dan pemikiran bangsanya. Hal ini berkaitan dengan sastra dan formasi pembentukan kesadaran kebangsaan, sastra sebagai refleksi, dan sastra sebagai layar proyeksi bangsa kita. Hal ini dipotret oleh Benedict Anderson (1991) tentang geografi imajinasi keindonesiaan dalam ruang sastra sebagai ruang resistensi dan ruang perlawanan. Hal ini sejalan dengan penelitian yang dilakukan oleh tim balai bahasa Propinsi Jawa Timur tentang embrio nasionalisme dalam karya Buya Hamka, Mas Marco Kartodikromo dan Kwee Tek Hoy. Ada asumsi bahwa sastra yang terbit sebelum kemerdekaan ini menjadi ruang pemikiran anak-anak bangsa tentang semangat kebangsaan. 
Semangat kebangsaan dalam sastra tersebut dijadikan indikator embrio nasionalisme sebelum kemerdekaan.

Tulisan pada masa itu, menjadi media yang strategis dalam menanamkan ideologis. Apalagi, sastrawan masa itu merupakan aktivis pers sekaligus aktivis politik. Tidak mengherankan jika wawasan kebangsaan oleh sastrawan didistribusikan dalam bentuk tulisan dalam media masa maupun sastra. Pada tahun 1930-an, tokoh-tokoh utama sastra seperti S.T. Alisjahbana, Sanusi Pane, Armin Hamzah menjadi pelopor dalam menebarkan wacana keindonesiaan melalui sastra. Ini ditengarahi oleh keterangan majalah Poedjangga Baroe tahun 1936 yang diubah menjadi "pembimbing semangat baru yang dinamis untuk membentuk kebudayaan persatuan Indonesia" (Rosidi, 2017:44). Tetralogi Bumi Manusia (1960-an) oleh Pramoedya Ananta Toer memberikan perlawanan dengan wacana pascakolonial. Wacana tersebut kerap kali dinilai sebagi pembakar semangat keindonesiaan. Oleh Alen (2004: 208) karya Pramoedya dinilai bisa dibaca sebagai esai tentang situasi kolonial yang memproduksi penjajah maupun yang dijajah. Para priyayi karya Umar Kayam, Burung-burung Manyar dan Burung-burung Rantau karya Y.B. Mangun Mangunwijaya juga melibatkan pandangan keindonesiaan sebagai wacana pasca-Indonesia (Allen, 2004: 209).

Sastra dapat menjadi media perlawan sekaligus protret pemikiran sebuah bangsa. Jika ditinjau dari wacana pascakolonial, sastra Indonesia dapat dikategorikan oleh Bandel (2014) sebagai sastra pascakolonial karena lahir dari bangsa yang pernah mengalami penjajahan (kolonialisasi). Untuk itu, narasi-narasi yang lahir dari sastra Indonesia diproduksi dari pertemuan budaya antra yang menjajah dan yang dijajah. Ada pertarungan dalam hegemoni kekuasaan di dalamnya. Namun tidak semua sastra Indonesia memuat wacana poskakolonial yang menarasikan pandangan untuk memperkuat semangat keindonesiaan.

Karya Iksaka Banu disinyalir memberikan wacana keindonesiaan dengan perspektif yang baru. Ada upaya yang dilakukannya dalam mendekonstruksi sejarah kolonialisme. Dia tidak menggambarkan sejarah dalam oposisi biner yang kaku antara warna hitam dan putih melulu, atau tokoh Eropa yang jahat dan pribumi yang baik. Ada persoalan yang digambarkan mengenai nilainilai kebangsaan yang bisa saja tumbuh dan diinisiasi dari keduanya, yakni antara pribumi dan Eropa. Melalui dialektika ketertindasan yang digambaran, dia menunjukkan bahwa represisi memunculkan resistensi dan menumbuhkan nilai nasionalisme. 
Penelitian ini dapat dikaitkan dengan dunia pendidikan. Sastra sebagai media dalam menyampaikan ideologi kebangsaan dapat digunakan untuk menanamkan semangat kebangsaan. Sastra, dalam dunia pendidikan, dipergunakan sebagai alat pengasah kepekaan jiwa. Maka dari itu, melalui pembacaan sastra, pengajar dapat menumbuhkan karakter pada generasi muda. Sebagaimana wacana keindonesiaan diasumsikan terdapat dalam kumpulan cerpen Semua Untuk Hinda Belanda, maka nilai-nilai nasionalisme tersebut perlu untuk diteliti. Dengan begitu, hasil penelitain ini dapat dipertimbangkan sebagai materi ajar matakuliah pengembangangan kepribadian dalam rangka menumbuhkan karakter kebangsaan. Dalam tulisan ini akan membahas bagaimana nilai-nilai nasionalisme yang ada pada kumpulan cerpen Semua Untuk Hindia?

\section{METODE PENELITIAN}

Penelitian ini menggunakan metode penelitian kualitatif-deskriptif, artinya data yang dianalisis dan hasil analisisnya berbentuk deskripsi potret nilai nasionalisme yang tergambar dalam kumpulan cerpen Semua untuk Hindia. Sementara itu, pendekatan yang digunakan dalam penelitian ini adalah pendekatan pascakolonial. Pendekatan ini digunakan dengan pertimbangan bahwa ada upaya dekonstruksi sejarah dalam kumpulan cerpen. Selain itu, wacana pascakolonial banyak diangkat sehingga melahirkan wawasan keindonesiaan.

Sumber data penelitian ini adalah Kumpulan Cerpen "Semua untuk Hindia" karya Iksaka Banu yang diterbitkan oleh KPG (Kepustakaan Populer Gramedia) dan merupakan cetakan kedua bulan Maret tahun 2018. Teknik pengumpulan data yang digunakan adalah teknik pustaka, simak, dan catat. Teknik Pustaka adalah teknik yang menggunakan sumber-sumber tertulis untuk memperoleh data. Teknik simak dan catat, yakni peneliti sebagai instrument kunci melakukan penyimakan secara cermat, terarah, dan teliti terhadap suebr data primer yaitu Kumpulan Cerpen "Semua untuk Hindia" karya Iksaka Banu. Hasil penyimakan itu dicatat sebagai data. Dalam data yang dicatat itu disertakan pula kode sumber datanya untuk pengecekan ulang terhadap sumber data ketika diperlukan dalam rangka analisis data.

Keabsahan data dilakukan dengan cara (1) mengamati teks secara tekun dan membaca berulang-ulang dengan penghayatan yang mendalam, (2) studi intertekstualitas, dan (3) diskusi dengan teman sejawat dan ahli. Pengamatan secara tekun dilakukan dengan membaca teks kumpulan cerpen Semua untuk Hindia yang dilakukan dengan cara berulang-ulang dan penghayatan mendalam untuk mengidentifikasi data secara tepat. Studi interteks dilakukan dengan 
mengahayati teks kumpulan cerpen dengan mengkaitkan terhadap wacana di luar teks yang berkaitan. Diskusi dengan teman sejawat dan ahli sastra dilakukan sebagai upaya pemantapan terhadap data yang relevan.

\section{HASIL PENELITIAN DAN PEMBAHASAN}

\section{Hakikat Nasionalisme Indonesia}

Nasionalisme berkembang di Eropa sebelum menyebar ke Asia dan Afrika. Perkembangan nasionalisme di Asia dan Afrika tidak lepas dari pengaruh kolonialisme dan imperialisme bangsabangsa Eropa. Menurut Hans Kohn, nasionalisme adalah gagasan yang mendorong manusia untuk menerjemahkan kesadarannya dalam tindakan yang teorganisir, dan satu bentuk tertinggi dari tindakan yang terorganisir itu adalah negara berdaulat. Nasionalisme menurutnya mewujud dalam nation-state. Terbentuknya nasion-state memperkuat nasionalisme. Definisi dan penjelasan nasionalisme dari Hans Kohn dilatar-belakangi oleh alam pikiran Eropa Barat. Hans Kohn membedakan, kemunculan nasionalisme di Eropa Barat dan di luar Eropa barat. Di Eropa Barat kemunculan nasionalisme merupakan sebuah peristiwa politik, pada awalnya yang mempunyai kedaulatan tertinggi adalah raja kemudian bertransformasi menjadi kedaulatan rakyat. Nasionalisme di Eropa Barat terkait erat dengan ide kebebasan individu dan kosmopolitanisme rasional. Kelas menengah sekuler yang merupakan produk baru Renaisans dan Reformasi berperan sebagai penggerak utama dalam nasionalisme di Eropa Barat (Budiawan, 2017: 38).

Di Eropa Tengah dan Timur, nasionalisme muncul karena reaksi atau perlawanan terhadap negara yang sudah ada. Dalam prosesnya, yang terjadi bukan lagi transformasi dari kedaulatan raja ke kedaulatan rakyat, tetapi lebih ke penyesuaian batas-batas negara dan batas-batas etnis. Konsekuensinya nasionalisme jenis ini sangat bersandar pada sentimen etnis dan ingatan atau mitos-mitos bersama yang mengikat komunitas-komunitas tersebut. Hans Kohn mengelompokkan nasionalisme Eropa Barat dengan sebutan civic nationalism, sedangkan nasionalisme di luar Eropa Barat disebut sebagai ethno nationalism. Gagasan Hans Kohn mendapat sanggahan dari beberapa pakar nasionalisme. Seperti Jaskulowski, yang mengganggap bahwa kategori nasionalisme yang dikemukakan oleh Hans Kohn terlalu sederhana, karena setiap negara mempunyai dinamika yang berbeda dalam perjalanan nasionalismenya (Budiawan, 2017: 38-39).

Ernest Gellner memberikan gambaran tentang nasionalisme merupakan suatu prinsip politik yang menyatakan bahwa politik dan unit nasional harus selaras. Sedangkan Benedict 
Anderson dalam bukunya Imagined Community (1988) mendefinisikan nasionalisme dipunyai oleh sebuah bangsa. Bangsa merupakan komunitas politis dan dibayangkan sebagai suatu yang bersifat terbatas secara kodrati sekaligus berkedaulatan. Kesamaan pemikiran antara Gellner dan Anderson bahwa nasionalisme merupakan pencarian konstruksi ideologis untuk mempertegas garis antara identitas kultural dan negara dan menciptakan sebuah komunitas bersama yang mengikat semua secara baru (Dwikoratno dan Lani (Eds), 2012: 163).

Berkembangnya nasionalisme di Asia dan Afrika berbeda dengan Eropa, termasuk Indonesia. Tumbuhnya nasionalisme Indonesia didominasi oleh pengaruh kolonialisme dan imperialisme yang dilakukan oleh penjajah (Belanda). Semangat nasionalisme Indonesia melawan penjajahan sudah ditunjukkan sejak masa kerajaan-kerajaan Islam. Akan tetapi perlawanan yang hanya bersifat fisik tersebut mengakibatkan kekalahan karena masih bersifat kedaerahan. Belum terbentuk kesadaran untuk bersatu, seperti perlawanan-perlawanan di negara modern. Lebih lanjut, Yudi Latif mengemukakan bahwa nasionalisme pada masa kerajaan-kerajaan Islam, merupakan nasionalisme yang berbasis agama. Beliau memberi sebutan nasionalisme pada masa tersebut sebagai nasionalisme purba (Latif, 2015: 272-273)

Titik balik perlawanan terhadap penjajah di Indonesia adalah peristiwa pergerakan nasional. Dimulai tahun 1908, berdirinya sebuah organisasi pergerakan (Budi Utomo), merupakan awal mula transformasi perjuangan rakyat Indonesia lepas dari penjajahan. Organisasi-organisasi pergerakan tidak berjuang secara fisik, akan tetapi secara politik melalui organisasi. Ada semangat untuk bersatu dalam melawan penjajahan, dan mulai berpikir secara rasional bahwa perlawanan harus menggunakan strategi (Wulandari dkk, 2017: 83).

Organisasi terbesar kedua yang menyadarkan semangat nasionalisme bahkan melahirkan tokoh-tokoh besar, yakni Sarekat Islam (SI) yang diketuai oleh HOS Tjokroaminoto. Berkembangnya SI menumbuhkan semangat nasionalisme yang berkerakyatan dan bersifat religius, karena landasan berdirinya SI adalah agama Islam. Lebih lanjut, sisi positif SI berani meninggalkan budaya-budaya lokal yang menghambat kemajuan (Hariyono, 2014: 76). Yudi Latif (2015: 304) mengkategorikan nasionalisme yang timbul di akhir tahun 1800-an hingga awal tahun 1900 an dalam dua faktor. Yang pertama, adanya titik temu dalam agenda publik yang berpusat pada isu kemajuan, kesejahteraan umum, dan pentingnya persatuan nasional yang dibangun oleh wacana-wacana dalam pers venakular. Yang kedua, adanya afiliasi berganda yang berfungsi sebagai jembatan diantara perhimpunan-perhimpunan. Kebanyakan gerakan-gerakan 
nasionalisme tua (proto-nasionalis) tidak bermula sebagai partai politik yang sudah terstruktur, tetapi lebih sebagai gerakan-gerakan sosial yang teorganisir secara longgar. Pada saat itu satu orang bisa menjadi anggota dari dua atau lebih perhimpunan. Melalui peran ganda tersebut, para nasionalis tua mampu untuk berkoordinasi dengan berbagai perhimpunan sehingga memudahkan pertukara informasi, agenda, dan sumber daya.

Latif (2015: 3015) mengkategorikan nasionalisme modern mulai terjadi pada tahun 1920 an. Pada masa ini sudah jelas terbentuk partai politik yang lebih terstruktur. Mislnya, semangat nasionalisme dikobarkan oleh Perserikatan Nasional Indonesia (PNI) yang dipelopori oleh Soekarno. Perlu diketahui bahwa Soekarno merupakan anak didik HOS Tjokroaminoto. Soekarno berusaha menyatukan antara nasionalisme, marxisme, dan Islam dalam melawan penjajah. Selanjutnya Hariyono (2014: 78-79) para pemuda Indonesia yang sedang menuntut ilmu di negeri Belanda mendirikan sebuah organisasi Perhimpunan Indonesia (PI). PI berusaha menggabungkan nasionalisme dan demokrasi sebagai landasan perjuangannya. PI merupakan satu-satunya organisasi pergerakan yang berani mengatakan tujuannya adalah Indonesia Merdeka, tujuan tersebut dijadikan sebagai nama majalah PI. Nasionalisme tidak hanya di dunia politik tetapi nasionalisme harus mencakup dunia ekonomi dan budaya.

Sebagai kesimpulan, pernyatan Hariyono (2014: 63) nasionalisme Indonesia bukan sekedar alat untuk melawan kolonialisme. Nasionalisme Indonesia bukan sekedar diorientasikan ke luar untuk membedakan dengan bangsa lain. Nasionalisme Indonesia juga berorientasi ke dalam, yaitu nasionalisme yang dapat membangun perasaan dan semangat untuk maju dan meningkatkan kesejahteraan bangsa. Etos kebangsaan yang inklusif, manusiawi, dan berkeadilan serta menghargai motif berprestasi menjadi dambaan pendiri bangsa.

Setelah mengkaji dinamika nasionalisme yang terjadi di Eropa hingga mempengaruhi Indonesia, peneliti menganggap perlu adanya identifikasi nasionalisme Indonesia berdasarkan perjalanan sejarahnya. Lahirnya nasionalisme Indonesia memang terpengaruh oleh Eropa, tetapi sosio-kultural masyarakat Indonesia sangat berbeda dengan Eropa. Lahirnya nasionalisme kita karena kondisi penjajahan sehingga memaksa bangsa Indonesia pada saat itu untuk bebas dari penjajahan Eropa. Semangat nasionalisme yang muncul sangat dipengaruhi oleh religusitas bangsa yang sebelum menjadi bangsa terjajah sudah lebih dulu dipengaruhi oleh agama. Dapat disimpulkan, nasionalisme yang terlihat semasa penjajahan (dalam dekade 1800-1900an) yakni: nasionalisme yang berbasis pada religiusitas (nasionalisme religius), nasionalisme yang 
berkemanusiaan (nasionalisme humanis), nasionalisme kerakyatan (nasionalisme politik), dan nasionalisme berkeadilan (nasionalisme ekonomi).

\section{Kumpulan Cerpen Semua untuk Hindia: Sastra dan Wacana Pascakolonial}

Pascakolonial merujuk pada masa setelah adanya kolonialisme. Dalam kolonialisme, suatu bangsa tidak sekedar menduduki wilayah bangsa lain, tetapi memiliki kuasa dan kontrol terhadap segala aspek: politik, ekonomi, pendidikan, teknologi, dan sebagainya demi kepentingan bangsanya sendiri. Menetapnya bangsa penjajah di wilayah bangsa jajahan menjadikan tempat itu sebagai wilayah pesingungan dan pertemuan kedua kebudayan. Kedua budaya saling memengaruhi dan berinteraksi, namun bukan sebagai kekuatan yang setara. Pertemuan kedua kebudayaan tersebut menjadi titik yang disoroti oleh wacana pascakolonial.

Indonesia merupakan negara pascakolonial. Narasi yang lahir dari narasi sastra, budaya, maupun, media dapat dikategorikan sebagai narasi pascakolonial. Menurut Setiawan (2018), kesengsaraan, penindasan, dan berbagai hal yang terkait dengan perampasan hak asasi manusia merupakan tajuk yang diekspos dalam teks-teks penjajahan. Dalam pandangan Setiawan, lepas dari penjajahan maka tidak berarti sisa-sisa yang dihasilkan penjajah lantas hilang. Hal ini karena pertemuan antara dua budaya. Maka dari itu, secara tidak langsung, narasi politik, identias, mentalitas, dan budaya bangsa Indonesia masih berada di bawah bayang-bayang budaya penjajah. Oleh Bandel (2013: 140), narasi dalam teks sastra yang diproduki oleh bangsa Indonesia dapat dikategorikan sebagai narasi sastra pascakolonial.

Wacana pascakolonialisme bukan sekedar mendeskripsikan dan memaparkan keadaan suatu bangsa yang mengalami penjajahan. Akan tetapi, wacana ini lebih pada sebuah perlawanan. Ada ruang represi atau penindasan yang disadarkan. Dari situ, muncullah ruang resistensi atau perlawanan. Dalam ruang resistensi itulah, semangat kebangsaan tumbuh.

Karya sastra pascakolonial merupakan analisis kritis berbentuk sastra, ditulis oleh sastrawan yang sadar akan kondisi pascakolonial dan memiliki semangat perlawanan terhadap neokolonialisme Bandel (2013: 140). Sastra pascakolonial memiliki ciri yang khas dengan dipengaruhi wacana negara pascakolonial.

Menurut pandangan Ratna (2007) karya sastra patut dianalisis dengan pendekatan pascakolonial dengan alasan sebagai berikut. 
1. Menampilkan sistem komunikasi antara pengirim dan peneriam, sebagai mediator antara masa lampau dan masa sekarang.

2. Menampilkan berbagai problematika kehidupan, emosionalitas dan intelektualitas, kisik dan fakta, di mana karya sastra adalah masyarakat itu sendiri.

3. Tidak terikat oleh ruang dan waktu, kontemporeritas adalah manifestasi yang paling signifikan.

4. Permasalahan dilukiskan secara simbolis, terselubung, sehingga tujuan-tujuan yang sesungguhnya tidak tampak. Dalam hal ini, ideologi oriental ditanamkan, di sini pula analisis dekonstruksi pacakolonoial dilakukan.

Kajian kritis sastra pascakolonial dilakukan untuk mengkitisi dampak kolonioalisme pada suatu bangsa. Untuk itu, kritik sastra pascakolonial juga menawarkan sebuah resistensi atas inferioritas bangsa terjajah, serta kondisi masyarakatnya. Dalam hal ini, ada sebuah gerakan kebudayaan tertentu yang dianggap sebagai reaksi atas belenggu. Logika dekonstruksi merupakan senjata utama dalam melakukan perlawanan atas dampak kolonialisme, yang paling terasa adalah dampak secara mental (Setiawan, 2018: 11)

Iksaka Banu, penulis kumpulan cerpen berjudul "Semua untuk Hindia" merupakan kumpulan cerpen dengan latar bertema sejarah dan dibalut oleh bahasa sastra yang sangat bagus. Perpaduan antara sejarah dan sastra yang sangat seimbang dalam buku ini dapat memunculkan pertanyaan yang mungkin memunculkan dilema. Sebenarnya buku ini bisa dikategorikan buku sejarah ataukah sastra? Itulah mengapa mungkin Bapak Nirwan Dewanto selaku budayawan mengatakan bahwa buku ini "Dalam berfiksi, sikapnya tetap ilmiah".

Terdapat beberapa judul cerita pendek dari buku yang diterbitkan oleh Kepustakaan Populer Gramedia antara lain berjudul Selamat Tinggal Hindia, Stambul Dua Pedang, Keringat dan Susu, Racun untuk Tuan, Gudang Nomor 012B, Semua untuk Hindia, Tangan Ratu Adil, Pollux, Di Ujung Belati, Bintang Jatuh, Penunjuk Jalan, Mawar di Kanal Macan, dan Penabur Benih. Mengutip Nirwan Dewanto "Jika teh manis tetaplah harus mengandung pahit supaya tak kehilangan rasa tehnya" begitu juga dengann cerita-cerita yang disajikan oleh buku ini. Cerita sejarah yang disajikan Nampak begitu manis dibalut oleh bahasanya, meskipun harus merasakan pahit pada setiap plot ceritanya.

Cerpen-cerpen dalam Semua Untuk Hindia syarat dengan nilai-nilai nasionalisme. Bahkan sangat relevan dikaji dengan nasionalisme ala Pancasila, yakni nasionalisme religius, nasionalisme 
kemanusiaan, nasionalisme berkerakyatan, dan nasionalisme berkeadilan. Walaupun, cerita yang disampaikan dalam kumpulan cerpen tersebut sebagian besar mengambil latar di masa kolonialisme. Wacana yang dinarasikan melalui sikap dan perilaku tokoh yang digambarkan melampaui masanya, yakni tokoh-tokoh orang Belanda pada masa itu meskipun sebagai kolonialisme, ternyata mereka memiliki empati kepada pribumi. Begitu juga, pribumi, tidak selalu digambarkan sebagai yang tertindas, ada beberapa cerita yang menggambarkan bahwa pribumi berkawan baik dengan orang Eropa dan sebaliknya. Kedua tokoh sama-sama mencintai tanah airnya, akan tetapi tokoh-tokoh tersebut sebagian seorang nasionalis yang mengedepankan rasa kemanusiaan. Ternyata wacana nasionalisme chauvinistic yang selama ini diyakini sebagai nasionalisme yang dianut oleh bangsa Eropa tidak semua orang Eropa meyakininya juga.

\section{Nilai-Nilai Nasionalisme dalam Kumpulan Cerpen Semua Untuk Hindia}

Lahirnya nasionalisme kita karena kondisi penjajahan sehingga memaksa bangsa Indonesia pada saat itu untuk bebas dari penjajahan Eropa. Semangat nasionalisme yang muncul sangat dipengaruhi oleh religusitas bangsa yang sebelum menjadi bangsa terjajah sudah lebih dulu dipengaruhi oleh agama. Dapat disimpulkan, nasionalisme yang terlihat semasa penjajahan (dalam dekade 1800-1900an) yakni: nasionalisme yang berbasis pada religiusitas (nasionalisme religius), nasionalisme yang berkemanusiaan (nasionalisme humanis), nasionalisme kerakyatan (nasionalisme politik), dan nasionalisme berkeadilan (nasionalisme ekonomi). Dari keempat nilai nasionalisme tersebut, nasionalisme yang paling dominan dan hampir ada di setiap cerpen adalah nilai nasionalime kemanusiaan. Berikut adalah pembahasan dari nilai-nilai nasionalisme tersebut.

\section{Nasionalisme Religius}

Nasionalisme religius adalah ajaran sistem yang mengatur keimanan (kepercayaan) dan peribadatan kepada Tuhan Yang Mahakuasa serta tata kaidah yang berhubungan dengan pergaulan manusia dan lingkungannya. Agama dan pandangan hidup kebanyakan orang menekankan kepada ketentraman batin, keselarasan dan keseimbangan, serta sikap menerima terhadap apa yang terjadi. Pandangan hidup yang demikian jelas memperhatikan bahwa apa yang dicari adalah kebahagiaan jiwa, sebab agama adalah pakaian hati, batin atau jiwa (Yulsafi dan Fusrida, 2018). Kumpulan cerita pendek Semua Untuk Hindia karya Iksaka Banu, menurut peneliti unik karena menggunakan latar masa colonial belanda di Indonesia. Oleh sebab itu sikap religius yang banyak menjadi 
sorotan adalah bagaimana sikap warga kulit putih (orang Belanda) bersikap ketika mereka menganut agama Kristen. Hal ini terlihat ketika seorang anggota militer pemerintah Hindia Belanda yang memiliki kemampuan lebih daripada rekan-rekannya tetapi dimanfaatkan oleh atasannya untuk hal yang tidak baik, yakni membunuh rekan atasan yang dianggap sebagai saingannya. Gejolak hati sang bawahan yang diperankan oleh tokoh Jacob Maurits Goedaerd, meskipun mendapat perintah atasan yang tidak dapat ia tolak serta mendapat bonus besar ia merasa hal tersebut merupakan perbuatan dosa. Berikut kutipan percakapan dalah hatinya yang berkecamuk dan menunjukkan kebimbangannya akan perbuatannya:

"Kusesali kemampuan militerku yang jauh di atas rekan-rekanku, sehingga membuat diriku mudah terlihat, kemudian disalahgunakan oleh penguas. Ya, aku Jacob Maurits Goedaerd, bukan lagi prajurit. Aku pembunuh bayaran. Lebih rendah daripada perampok. Perampok menatap mata korbannya, sedang aku menembak dari belakang. Tetapi bonus itu mungkin bisa menebus dosaku. Aku akan keluar dari dinas dan memulai hidup baru..." (Bintang Jatuh Hal. 113).

Nilai religius merupakan nilai yang bersumber dari kebenaran tertinggi yang datangnya dari Tuhan dan ruang lingkup nilai ini sangat luas mengatur seluruh aspek kehidupan manusia. Religius merupakan konsep mengenai penghargaan tinggi yang diberikan oleh warga masyarakat kepada beberapa masalah pokok dalam kehidupan keagamaan yang bersifat suci sehingga dijadikan pedoman bagi tingkah laku keagamaan warga masyarakat yang bersangkutan. Lebih lanjut, seseorang yang religius diartikan sebagai manusia yang berarti, yang berhati nurani serius, saleh, teliti, dan penuh dengan pertimbangan spiritual (lathief dalam Nengsih dkk, 2019). Nasionalisme religius merupakan sikap nasionalisme yang didasari oleh religiusitas, dimana seseorang yang mencintai tanah airnya karena ia sadar bahwa tanah air dan seisinya merupakan ciptaan Tuhan. Oleh sebab itu, mereka memiliki kesadaran untuk bersikap menjaga tanah air dan seisinya.

Negara Belanda dimasa colonial meskipun menganut paham liberal dan sekuler, tetapi dalam kegiatan kenegaraan mereka mengikutsertakan rahmat Tuhan. Cerpen yang berjudul Penabur Benih menggambarkan, ketika pemerintah Belanda mengirimkan kapal dagang dari Belanda menuju Hindia Belanda, dalam kapal tersebut diikutsertakan seorang Pastur muda bernama Jacob dan sang guru yang bernama Pater Van der Gracht. Perjalanan yang mengikutsertakan pendoa memiliki harapan bahwa mereka yang melakukan perjalanan senantia mendapat keselamatan hingga mencapai tempat tujuan. Dalam cerpen tersebut diceritakan bahwa, 
sebagian besar penumpang dalam kapal tersebut terjangkit penyakit scheurbuik dan banyak penumpang yang mati dalam kapal tersebut. Pastur dan sang guru merupakan penganut agama Katholik, sedangkan sebagian besar penumpang menganut agama Kristen Protestan. Hal tersebut membuat kedua pendoa merasa mereka mendapat kutukan karena membawa pendosa, memang antara agama Katolik dan Protestan pada masa itu tidak akur di Eropa termasuk di Belanda. Sang guru Pastur merasa marah karena, ia juga merasa bahwa wabah yang menyebar di kapal selama perjalanan tersebut berlangsung karena murka Tuhan terhadap para pendosa protestan tersebut. Dalam keadaan demikian, sang guru Pastur bersama dengan kepala urusan dagang yang bernama Elias Goeswijn berdoa bersama untuk keselamatan kapal yang sedang mereka tumpangi. Kutipan berikut menceritakan bagaimana keadaan kapal yang ditumpangi oleh kepala urusan dagang, Pastur muda, dan Sang Guru Pastur tersebut:

"Belum berakhir, mijnheer. Cobalah miliki sedikit iman. Tuhan masih bersama kita, Pater Van der Gracht menyentuh pundak Elias Goeswijn."

"Aku tidak melihatmu di misa arwah tadi, padahal aku dan Jacob tidak membuat tanda salib dan doa yang kupilih cukup umum. Seharusnya kau hadir." (Penabur Benih, Hal. 146)

Tujuan perjalanan kapal dagang tersebut adalam Ambon. Ketika tiba di Ambon Sang guru pastur muda akan segera menyebarluaskan agama Katolik di Ambon sesuai dengan perintah dari Raja, Dewan Negara, dan Uskup. Kecintaannya pada negara membuat Pastur Muda dan Gurunya rela menempuh perjalanan jauh untuk menyebarluaskan agama Katolik. Berikut kutipan percakapan di kapal yang menceritakan apa yang akan mereka lakukan sesampainya di HindiaBelanda.

“Anak muda!" Pater memukulkan tongkatnya ke geladak. "Pesan itu ada di dalam surat yang ditandatangani Raja, Dewan Negara, dan Uskup. Dengan atau tanpa bantuan kalian semua, bila masih hidup, setiba di sana aku akan tetap melakukannya. Menjadi penabur benih. Mengikuti jejak Fransiskus Xaverius di Ambonial..." (Penabur Benih, Hal. 149)

\section{Nasionalisme Kemanusiaan}

Nilai kemanusiaan merupakan suatu nilai yang lahir di masyarakat karena adanya fenomena sosial yang mampu memberikan pengaruh baik dan dampak positif bagi masyarakat. Nilai-nilai kemanusiaan diarahkan pada pembentukan pribadi manusia sebagai makhluk sosial (Anilan Pusba dalam Permata dkk, 2014). Refleksi nilai-nilai kemanusiaan dalam sebuah karya sastra diharapkan mampu mengubah pribadi seseorang sesuai dengan pemahamannya terhadap sebuah nilai tersebut. Lebih jauh, adanya analisis mengenai nilai kemanusiaan dalam karya sastra 
akan lebih memudahkan pembaca atau masyarakat memahami mengenai nilai kemanusiaan yang terdapat dalam karya sastra tersebut, sehingga pembaca lebih mudah mengaplikasikan nilai kemanusiaa dalam kehidupan sehari-hari Permata dkk, 2014). Karyono (2008) menjelaskan bahwa nilai-nilai kemanusiaan itu mencerminkan kedudukan manusia sebagai makhluk tertinggi di antara makhluk-makhluk lainnya. Seseorang yang mempunyai nilai-nilai kemanusiaan yang tinggi menghendaki masyarakat memiliki sikap dan perilaku sebagai layaknya manusia.

Bolo dkk (2012) kemanusiaan mengandaikan pengakuan bahwa manusia apapun latar belakangnya setara dan bebas. Sedangkan nasionalisme berperikemanusiaan dinyatakan bahwa segala bangsa menyiratkan pengakuan bahwa baik setiap bangsa adalah setara. Kesetaraan bukan hanya hak tetapi merupakan kenyataan berdasarkan 10 kemampuan manusiawi yang mendasar dan fungsi kemampuan dasar sebagai manusia. Adapun 10 kemampuan manusiawi mendasar yakni: (1) hidup; (2) kesehatan fisik; (3) keutuhan tubuh; (4) pancaindra, imajinasi, dan pikiran; (5) afeksi yang sehat (kesehatan emosional); (6) nalar praktis; (7) afiliasi (hidup bersama dan kepedulian terhadap sesame, pengakuan dan penghargaan sebagai pribadi dalam masyarakat); (8) berelasi harmonis dengan makhluk lain; (9) bermain; (10) penataan lingkungan sekitar melalui keterlibatan politis dan hak milik pribadi.

Mengutip dari Soekarno dalam Bolo dkk (2012) perikemanusiaan tidak bisa dilepaskan dari identitas diri sebagai suku, bangsa, atau kebudayaan tertentu. Identitas diri sebagai suatu bangsa jangan sampai bersifat tertutup, atau chauvinistic dan rasialistik. Perikemanusiaan hendaknya bersifat terbuka, sehingga antar satu bangsa dengan bangsa yang lain adalah setara dan layak menghormati satu sama lain. Hal ini sejalan dengan nasionalisme yang berperikemanusiaan, yakni nasionalisme yang internasionalisme. Hal tersebut bermaksdu bahwa nasionalisme yang tidak terbatas hanya pada bangsanya sendiri, tetapi nasionalisme yang mendukung pergaulan antar bangsa, sehingga menyamarkan atau menghapus batas-batas negara.

Dalam kumpulan cerpen Iksaka Banu, beberapa cerita pendek menggambarkan nasionalisme berperikemanusiaan antar bangsa, misalnya antara bangsa Belanda dengan pribumi. Seperti yang diceritakan pad acer[en ke 6 dengan judul Semua Untuk Hindia. Tokoh dalam cerita tersebut adalah Tuan De Wit seorang jurnalis senior berkebangsaan Belanda yang memiliki sahabat warga pribumi dari Bali bernama Anak Agung Istri Suandani. Ketika Raja Badung tetap mempertahankan tradisi lokalnya yakni "mesati" dan Raja tersebut mendapat tuduhan menolak kebijakan denda dari pemerintah Hindia-Belanda, serta melindungi pelaku perampokan kapal. 
Ketika terjadi perang antara pemerintah Hindia-Belanda dengan Kerajaan Bali, Anak Agung Istri Suandani menuliskan surat pada sahabatnya, Tuan De Wit, seperti digambarkan dalam kutipan berikut:

"Tuan De Wit yang baik, saya tak takut kehilangan jiwa. Memiliki atau kehilangan jiwa kuasa Hyang Widhi Semata. Saya hanya sulit membayangkan keadaan seusai perang, terlebih bila kami di pihak yang kalah. Adakah kehidupan bila kemerdekaan terampas?" (Semua Untuk Hindia, Hal. 61).

Persahabatan antara dua orang yang berbeda kebangsaan tersebut tetap berlangsung meskipun dalam keadaan perang. Persahabatan antar kedua orang tersebut mengaburkan batasbatas kebangsaan antar keduanya. Meskipun posisi pada saat itu, warga pribumi dalam kondisi dijajah, tetapi masih ada orang-orang berkebangsaan eropa yang mengedepankan kemanusiaannya sehingga bersahabat dengan warga probumi. Dalam cerpen yang sama, Tuan De Wit membalas surat yang telah dikirimkan oleh sahabatnya.

"Engkau memintaku berdoa agar perang dibatalkan? Wahai Adik kecil, telah berabad kami terjangkit penyakit gila kebesaran. Kurasa Tuhan pun enggan mendengar doa kami. Sudah lama pula kami tak bisa menghormati kedaulatan orang lain. Saat menerobos puri bersama pasukan siang tadi, anggota tubuhku seolah ikut berguguran setiapkali prajurit menemukan sasaran perusakan: Payung-payung taman, tempat kita pernah duduk berbincang, penyekat ruang, guci-guci suci. Percuma berteriak melarang. Penjarahan dilakukan bukan oleh tentara bumiputra saja, para perwira Eropa pun terlibat." (Semua Untuk Hindia, Hal. 64).

Nilai nasionalisme kemanusiaan sangat jelas digambarkan pada cerpen ke 9 yang berjudul Di Ujung Belati. Tokoh utama dalam cerpen tersebut adalah Letnan Fabian Grijs sebagai Letnan Belanda yang memiliki karir bagus dan Sabeni sebagai Kepala Mandor. Diceritakan bahwa terjadi amukan massa yang disebabkan oleh penghasut yakni mandor Sabeni. Letnan yang tidak berdaya dalam pergolakan tersebut ditolong oleh bawahannya Marsekal Deandels. Letnan Fabian merasa dikhianati oleh mandornya, memberikan pelajaran dengan mencongkel mata kanan dengan menggunakan sebuah belati. Sang Letnan merasa telah mengangkat derajat si mandor, tetapi si mandor sulit setia kepada pemerintahan Belanda. Bahkan, Letnan Fabian mengancam bahwa hidup Sabeni ada di ujung belatinya. Tak lama kemudian, terjadi penyerangan Inggris ke benteng pertahanan Belanda. Inggris memiliki strategi yang bagus sehingga melumpuhkan Belanda dnegan mudah dan berhasil menguasai benteng Belanda. Letnan Fabian mencoba menyelamatkan diri 
tetapi tertangkap oleh mata-mata Inggris, tak lain adalah Sabeni. Kemudian, Sabeni membebaskan letnan tersebut dengan berkata:

"Tuan apakah kau sadar hidupmu ada di tanganku?" "Terimakasih telah mengangkatku dari sampah."

Peristiwa tersebut menjadi refleksi bagi pemerintahan Hindia-Belanda terutama sang Letnan, bahwa apa yang dilakukan oleh pemerintah Inggris terhadap jajahannya lebih manusiawi sehingga rakyat jajahannya patuh dan setia, seperti diceritakan dalam kutipan berikut:

"Sersan, orang Inggris memang congkak, tetapi kurasa mereka benar. Dengan menjaga kemurnian tradisi Barat yang tinggi, penduduk asli akan menaruh hormat pada kita. Lihat pasukan Inggris. Berapa banyak prajurit Eropa di sana? Hanya Sepertiga. Sisanya adalah laskar Bengal dan Madras dari India, yang setia pada Raja Inggris," kataku. "Jadi, bukan kita yang turun, merekalah yang perlahan kita naikkan derajatnya menjadi bangsa yang beradab." (Di Ujung Belati, Hal 94)

Pada cerpen Penunjuk Jalan yang diperankan oleh seorang dokter Belanda bernama Jorijs Handlanger dan Pangeran Bumiputera. Dokter Jorijs Handlanger dikirim ke Hindia-Belanda untuk menanggulangi wabah penyakit perut dan beri-beri parah. Karena di Pelabuhan Batavia sedang dilakukan perbaikan, maka harus mendarat di pelabuhan Banten. Ternyata, dalam perjalanan menuju Batavia, kereta kuda yang ditumpangi dokter terperosok ke tebing dan mengakibatkan teman si dokter yakni Joep terluka parah. Sang dokter mencoba mencari bantuan dan bertemu dengan segerombolan bumiputera yang menaiki kuda dna kereta kuda. Dokter menyampaikan maksudnya untuk meminta pertolongan, dan pemimpin gerombolan tersebut bersedia membawa dokter dan Joep ke perkemahannya untuk disembuhkan. Keesokan harinya, setelah Joep sedikit membaik, sang pangeran menunjukkan jalan terdekat ke Batavia. Ketika meminat pertolongan, dr. Jorijs merasa takut jika segerombolan yang menghampirinya adanya kelompok perampok, tetapi ternyata mereka bersedia menolong meskipun tau sang dokter orang Eropa. Hal tersebut digambarkan dalam kutipan percakapan berikut:

“... si pemuda melepaskan tatapannya. Ketegangan mencair. "Aku pernah tinggal di keluarga Belanda yang kerap berurusan dengan Chirurgijnen.* Aku tau benar pekerjaanmu, Tuan Dokter," ujarnya dalam bahasa Belanda. Ya, Belanda!" "Donder en bliksem!" aku melompat mundur. "Betapa fasih. Pujianku untuk Tuan," lanjutku. Kali ini sepenuhnya dalam Bahasa Belanda. (Penunjuk Jalan, Hal 120) “... sebaiknya Tuan ikut kami. Biarkan porter itu mendapat perawatan. Besok pagi kamu tunjukkan jalan tersingkat ke Batavia.” (Penunjuk Jalan, Halaman 122). 
Selanjutnya, nilai nasionalisme berperikemanusiaan terlihat dari cerpen terakhir yang berjudul Penabur Benih. Cerpen menggambarkan tokoh utama Pastur Belanda bernama Jacob dan gurunya Pater Van Der Gracht. Kedua pemuka agama tersebut dikirim ke Hindia-Belanda dengan tujuan menyebarluaskan agama Katolik di Hindia-Belanda. Dalam perjalanannya di kapal, ternyata banyak penumpang yang terjangkit penyakit scheurbuik dan sebagian besar dari mereka mati dalam kapal tersebut. Kedua orang pemuka agama beragama Katolik sedangkan para penumpang beragama protestan. Meskipun berbeda keyakinan, Pater Van der Gracht bersedia memimpin doa untuk mendoakan para penumpang yang terjangkit penyakit. Kemauan tersebut digambarkan dalam kutipan percakapan berikut:

"Sesuai arahan Pater Albrecht van der Gracht, doa arwah kubawakan dalam baahasa latin sepenuhnya sebelum tubuh kaku yang diberi pemberat itu dengan tergesa diluncurkan ke laut lewat sebilah papan... orang-orang di kapal memang keterlaluan. Tak kujumpai wajah berduka, belas kasih, ataupun penghargaan. Padahal sebelum menjadi mayat, ia adalah Letnan Meeus van Scheveningen, legenda perang Anwerpt yang selama ini kami hormati." (Penabur Benih, Hal. 152)

Barangkali kematian cepat dan beruntun akibat penyakit scheurbuik sejak keberangkatan dari pelabuhan Texel tahun lalu, seerta wabah zwarte dood pada perhentian di Madagaskar, telah mengubah hati kami menjadi tawar, dingin, dank eras." (Penabur Benih, Hal. 142)

"Kita segera berlabuh, "Elias Goeswijn menengok jam pasir di meja kapten. "Akan kuminta seseorang membuat peti mati. Kita bisa menyelenggarakan upacara pemakaman yang layak di darat. Tentunya engkau bisa memimpin doa, Nak?" (Penabur Benih, Hal. 152)

\section{Nasionalisme Kerakyatan}

Terbentuknya negara Indonesia dengan bersatunya keanekaragaman daerah, suku, bahasa dan agama tidak dapat terlepas dari perjuangan rakyat yang pada saat itu berhasil melakukan perlawanan dengan tenaga dan pemikirannya untuk menumpas penjajah. Sehingga Pendirian Negara Republik Indonesia ini menempatkan posisi rakyat di atas segala-galanya. Doktrin yang terbetuk berdasarkan doktrin kebangsaan dan kerakyatan merupakan doktrin yang berhubungan dengan kedaulatan rakyat. "Daulat Rakyat" berarti kepentingan rakyat adalah hak sosial rakyat, bahwa pemerintahan Negara dijalankan atas kehendak dan kepentingan rakyat, bahwa " Tahta adalah untuk Rakyat”. (SE, Swasono: 71)

Kumpulan Cerpen Semua untuk Hindia karya Iksaka Banu merupakan salah satu karya sastra yang banyak sekali menceritakan kehidupan perjuangan rakyat Indonesia di era 
Kolonialisme. Identitas mengenai latar belakang masyarakat pada masa itu dijelaskan secara beragam melalui kumpulan cerpennya. Sehingga banyak sekali cerita-cerita yang mengandung nilai kerakyatan, perjuangan, serta rasa Nasionalisme masyarakat pada saat itu. Ahmad Sahal dalam Aprinus Salam (2003) membicarakan mengenai nasionalisme sebagai satu sikap perlawanan terhadap narasi nasionalisme yang lebih mapan (kolonial). Kajian Sahal difokuskan terhadap karya Toer, yaitu Rumah Kaca.

Ada beberapa hal yang sedikit membedakan mengenai Karya Sastra Pramoedya Ananta Toer dengan Iksaka Banu. Karya Sastra yang ditulis oleh Pramoedya Ananta Toer banyak mewakilkan mengenai ketertindasan dan juga perlawanan rakyat Indonesia pada masa colonial, sedangkan cerita yang ditulis oleh Iksaka Banu dalam kumpulan cerpennya, tidak hanyak menggambarkan kesan hitam-putih, penjajah-pribumi. Akan tetapi, dalam cerpen Iksaka Banu banyak menceritakan mengenai banyak warna mengenai semangat Kerakyatan dalam membela tanah air yang tidak hanya dilakukan oleh masyarakat pribumi saja, akan tetapi juga dilakukan oleh orang-orang Belanda keturunan maupun Belanda totok yang saat itu sedang berada di Indonesia.

Nilai Nasionalisme Kerakyatan yang terkandung dalam Cerpen Semua untuk Hindia terdapat dalam salah satu judul cerpennya Selamat Tinggal Hindia halaman 12 "Aku membayangkan Geertje dan lesung pipitnya, duduk di tengah hamparan sawah, bernyanyi bersama orang-orang yang ia cintai: "Ini Tanahku. Apapun yang ada di ujung nasib, aku tetap tinggal di sini." Pada cerpen tersebut mengisahkan dua tokoh Belanda totok yakni seorang wartawan bernama Martinus Witkerk dan Geertje. Martinus Witkerk yang sedang mencari berita bertemu wanita Belanda bernama Geertje di camp penampungan. Martinus ingin membantunya pulang ke Belanda, akan tetapi ia menolak karena ia telah menyatu dengan Hindia. Hidup dan matinya ada di Hindia. Hal tersebut ada pada kutipan di bawah ini:

"Kita ada di tengah pergolakan besar dunia. Nilai-nilai bergeser. Setelah berabad, kita menyadari tanah ini bukan Ibu Pertiwi kita," jawabku. Untuk ketigakalinya kuminta, pergilah selai bisa,"

"Ke Belanda?" Geertje menurunkan tutup piano. "Aku bahkan tak tahu, di mana letak negara nenek moyangku itu."

"Di kampung halamanku, di Zundert, ada beberapa rumah kontrakan dengan harga terjangkau. Sambil menunggu kabar tentang ayahmu. Kau busa tinggal di sana."

"Terima kasih, Geertje tersenyum. "Kau sudah tahu di mana aku ingin tinggal." (Hal.10) 
Martinus menasihatinya bahwa yang dilakukannya berbahaya, akan tetapi Geertje tersinggung, ia merasa bertanggung jawab atas ketidak adilan yang dilakukan oleh Belanda, menurutnya revolusi tidak bisa dihentikan. Hal itu tercantum dalam kutipan di bawah ini:

"Bila api revolusi telah berkobar, tak ada yang bisa menahan," Geertje menghentikan laju jemarinya di atas tuts. "mereka hanya ingin mandiri, seperti kata ayah dulu. Ayah pengagum Sneevliet. Ia siap kehilangan hak-hak istimewa di sini. Aku sendiri seorang guru sekolah bumiputra. Lahir, besar ditengah bumiputra. Saat Jepang berkuasa, kusadari bahwa Hindia Belanda bersama segala keningratannya telah usai. Aku harus berani mengucapkan selamat tinggal kepadanya. Dan apa pun yng ada di ujung nasib, aku akan tetap tingal di sini. Bukan sebagai 'penguasa', seperti istilahmu. Entah sebagai apa. Jepang telah memberi pelajaran, pahitnya menjadi jongos atau babu. Setelah kemarin hidup makmur, bukankah memalukan lari di saat orang-orang ini butuh bimbingan kita?" (hal.12)

Puncak Konflik terjadi pada saat Rumah Geertje diserang dan diambil alih oleh NICA. Martinus baru mengetahui bahwa ternyata Geertje adalah tokoh pergerakan revolusi kemerdekaan Indonesia bersama orang-orang pribumi. Dia lah yang selama ini di radio dijuluki Ibu Pertiwi.

Dari beberapa kutipan di atas terkandung nilai nasionalisme kerakyatan, dimana nilai nasionalisme kerakyatan berarti bersatu padunya masyarakat untuk menjaga dan melindungi negara dari segala bentuk ancaman, baik dari dalam maupun luar negeri. Selain itu, nasionalisme kerakyatan juga didasarkan pada kesamaan nasib dan sepenanggungan diantara sesama rakyat sehingga memiliki kesanggupan untuk rela berkorban demi kepentingan bangsa dan negara apabila memang diperlukan. Identitas yang berbeda antara ras, suku, etnis digambarkan oleh tokoh Geertje sebagai Indo (peranakan Belanda) yang dianggap sebagai bagian atau golongan Belanda, justru malah menjadi "Ibu Pertiwi" yang turut serta dan melebur dengan pribumi untuk meraih kemerdekaan.

Dalam masyarakat posmodern, wacana multiidentitas tersebut menyebabkan seseorang membangun sekat-sekat imajiner, untuk mempertahankan identitas dirinya, secara individual. Sekat-sekat imajiner individual tersebut memberikan hubungan yang problematik dengan nasionalisme. Akan tetapi ternyata pada cerita tersebut Geertje sebagai Indo tidak memberlakukan hal tersebut, karena baginya Indonesia adalah "rumah" baginya dan dirinya sudah melebur dan menjadi satu bagian dengan rakyat Indonesia.

\section{Nasionalisme Berkeadilan}

Keadilan dalam berbagai sumber literatur sering dihubungkan nilai sikap dan karakter seseorang. Menurut Dwisvimiar secara umum seseorang yang bersikap tidak adil dihubungkan 
dengan seseorang yang tidak mematuhi peraturan (lawful, lawless) dan orang yang tidak fair (unfair). Karena mematuhi peraturan hukum adalah satu wujud dari keadilan, maka seluruh warga negara tidak terkecuali di Indonesia dituntut untuk bertindak adil, di mana tujuan dari peraturan hukum tersebut di buat adalah untuk mencapai kesejahteraan dan kebahagian seluruh masyarakat.

Di dalam kumpulan cerpen Semua untuk Hindia bentuk nilai keadilan banyak diceritakan dalam berbagai bentuk. Bentuk keadilan tersebut terdapat pada diri seseorang terhadap lingkungan sosialnya (fair) dan terhadap upaya penegakan hukum (law). Bentuk keadilan terhadap lingkungan sosial diceritakan terbalik dengan bentuk ketidakadilan (unfair). Sebagai contoh nilai keadilan yang digambarkan di suatu perkebunan tembakau.

"Fred, aku belum bisa memberi jawaban," Helena menunduk. "Terutama karena aku tak yakin bisa bertahan di sana. Kudengar kehidupan di perkebunan tembakau sangat keras. Banyak pemberontakan kuli. Entah di mana. Pernah kubaca kritik seorang pengacara atas perlakuan kejam para pengelola perkebunan terhadap kuli."

"Van den Brand?" tanyaku. Sebelum berangkat ke Hindia sudah kubaca brosurnya. Siapa pun akan berontak bila diperlakukan kasar. Sejauh ini kami berusaha tetap adil. Namun takkan kusangkal bahwa di lapangan bisa saja terjadi penyelewengan moral yang memicu penyerangan terhadap orang Eropa. Bukankah semua jenis pekerjaan memiliki resiko?"

Cerita pada judul menggambarkan seorang tokoh perempuan pribumi yang bernama Imah yang menjadi istri tokoh Laki-laki Belanda totok bernama Fred penjaga perkebunan. Saat lelaki ini pulang ke negeri asalnya, dia menikah lagi dengan perempuan Eropa secara resmi bernama Helena. Akan tetapi, Helena tidak bersedia untuk ikut fred ke Hindia dikarenakan takutnya pemberontakan oleh pribumi pekerja perkebunan. Akan tetapi, menurut Fred pemberontakan tersebut mungkin terjadi karena adanya tindakan unfair yang mungkin orang lakukan. Fred bersikukuh meyakinkan Helena bahwa dirinya telah berlaku adil, sehingga seharusnya tidak ada keraguan bagi Helena untuk mau pergi ke Hindia bersama Fred. Akan tetapi, sebetulnya ada satu bentuk ketidakadilan lain yang dia lakukan, yakni dengan menikahi Helena tanpa sepengetahuan Imah. Ketidakadilan tersebut dikemudian hari menyadarkan Fred dan membuatnya merasa telah menyakiti dan mengecewakan Imah, hal tersebut membuatnya merasa terancam. Rekan kerja dari Fred memberikan peringatan untuk berhati-hati terhadap nyai yang menurutnya bisa membahayakan dan membunuh diam-diam. Merasa sakit hati dan kecewa, tokoh nyai pergi meninggalkan rumah karena tergantikan oleh istri baru tanpa mengetahui apakah meninggalkan racun atau tidak. 
Berbicara mengenai Kolonialisme dalam konteks sejarah Indonesia, kolonialisme sendiri merupakan wujud dari ketidakadilan, keserakahan, diskriminasi dan penafian atas hak asasi manusia (Miftahuddin: 3). Padahal wujud dari perlawanan kolonialisme sendiri merupakan nasionalisme keadilan, hal tersebut diwujudkan dengan adanya Pancasila sebagai alat yang ampuh untuk mengusir penjajah atau kolonialisme. Sehingga setiap pribadi seseorang yang menjunjung tinggi nilai nasionalisme pasti akan mewujudkan keadilan dan penegakan hukum. Hal tersebut terdapat pada nukilan salah satu cerpen dari Iksaka Banu Di Ujung Belati "Enam serdadu dan Majoor Ijzerhard luka parah. Tapi hukum harus tetap ditegakkan. Semua, termasuk engkau, harus masuk bui. Belajar mengendalikan massa," sambung marsekal.

Auchmuty, merupakan seorang berkewarganegaraan Skotlandia yang bertugas sebagai Mayor Jenderal. Pemimpin Armada Inggris di India. Dalam suatu kerja rodi terjadi amukan masa yang ditengarai oleh penghasut yang tidak lain adalah mandor yang bernama Sabeni. Untungnya dalam pergolakan itu Letnan yang tidak berdaya mampu ditolong oleh Marsekal Daendels. Merasa dikhianati oleh Sabeni, Letnan Fabian memberikan pelajaran dengan mencongkel mata kanannya dengan menggunakan sebuah belati. Dia merasa telah mengangkatnya dari tumpukan sampah, akan tetapi sabeni masih sulit setia kepada pemerintahan Belanda, Fabian mengancam Sabeni Bahwa hidupnya ada diujung belatinya. Akan tetapi, tidak lama berselang terjadi terjadi Penyerangan atas Inggris ke benteng pertahanan Belanda, secepat kilat Inggris memiliki strategi yang bagus untuk melumpuhkan Belanda dan berhasil menguasai benteng Belanda. Letnan Fabian berhasil menyelamatkan diri dari serangan itu, akan tetapi dia berhasil ditemukan oleh mata-mata Inggris yang ternyata adalah Sabeni. Akan tetapi, dia dibebaskan oleh Sabeni dengan melontarkan kalimat yang pernah dilontarkan oleh Fabian "Tuan apakah kau sadar hidupmu ada ditanganku?" “terimakasih telah mengangkatku dari sampah."

Dari kutipan di atas terkandung nilai nasionalisme keadilan, meskipun Marsekal bukan orang Pribumi dan menerapkan nlai nasonalisme keadilan bagi Indonesia, akan tetapi penerapan keadilan dapat diterapkan berdasarkan komunitas tertentu. Benedict Anderson dalam Sulfikar menyatakan bahwa nasionalisme sebagai sebuah ide atas komunitas yang dibayangkan, imagined communities, sedangkan keadilan sendiri merupakan penerapan sikap taat hukum dan fair yang dilakukan oleh seseorang. Sehingga, meskipun marsekal bukan pribumi akan tetapi dia cukup untuk menegakkan nilai nasionalisme keadilan dimana mematuhi dan menaati peraturan negara 
dengan ikut serta dalam memelihara dan menjaga ketertiban masyarakat, bangsa dengan mematuhi aturan yang berlaku di negara/ komunitasnya.

\section{PENUTUP}

Peneliti menemukan nilai-nilai nasionalisme dalam kumpulan cerpen antara lain: (1) nasionalisme religius, (2) nasionalisme kemanusiaan, (3) nasionalisme keadilan, dan (4) asionalisme kerakyatan. Dari keempat nilai nasionalisme tersebut, nasionalisme yang paling dominan dan hampir ada di setiap cerpen adalah nilai nasionalime kemanusiaan. Dari hasil penelitian dan pembahasan, dapat disimpulkan bahwa kumpulan cerpen Semua untuk Hindia dapat digunakan sebagai pendukung bahan ajar di Perguruan Tinggi. Pendukung bahan ajar ini digunakan dengan sasaran mahasiswa pada berbagai jurusan dalam matakuliah pengembangan kepribadian maupan mata kuliah umum lain yang memiliki capaian karakter nasionalisme. Hal ini karena sastra merupakan bacaan yang dapat dinikmati semua kalangan, apalagi kumpulan cerpen tersebut memiliki nilai-nilai nasionalisme. Maka dari itu dibutuhkan rancangan yang tepat dalam desain pembelajaran untuk memasukkan bacaan sastra.

Dengan bacaan sastra yang mengandung nilai nasionalisme, pembelajaran menjadi lebih menyenangkan. Hal itu juga dapat menguatkan karakter peserta didik. Apaalagi nilai nasionalisme dalam kumpulan cerpen tersebut lebih difokuskan pada nilai nasionalisme kemanusiaan. Motif cerita dalam kumpulan cerpen pun cukup komplek, tidak melulu dangan pengambaran hitam dan putih, antara yang baik melawan yang jahat. Dengan demikian, bacaan itu bisa menetralisir adanya pemahaman nasionalisme ekstrim yang mengindahkan nilai-nilai kemanusiaan.

\section{DAFTAR PUSTAKA}

Adisusilo, Sutradjo. 2013. Sejarah Pemikiran Nasionalisme Eropa: Studi Kasus Nasionalisme Prancis dan Italia. Jakarta: Rajagrafindo Persada.

Allen, Pamela. 2004. Membaca dan Membaca Lagi: Reinterpretasi Fiksi Indonesia 1980-1995. Magelang: Indonesiatera.

Bandel, Katrin. 2013. Sastra Nasionalisme Pascakolonialitas. Yogyakarta: Pustaha Hariara

Bolo, A.D., B. Samho., S. Djunatan., S.K. Laku., 2012, Pancasila, Kekuatan Pembebas, Yogyakarta: Kanisius.

Budiawan. 2017. Nasion \& Nasionalisme (Jelajah Ringkas Teoritis), Yogyakarta: Ombak. 
Dwisvimiar, Inge. 2011. Keadilan dalam Perspektif Filsafat Ilmu Hukum: Jurnal Dinamika Umum. 11 (3): 522-531

Hariyono. 2014. Ideologi Pancasila Roh Progresif Nasionalisme Indonesia, Malang: Intrans Publishing.

Karyono, 2008, Nilai-Nilai Kemanusiaan dalam Novel Ketika Lampu Berwarna MerahKarya Hamsad Rangkuti, Tesis tidak dipublikasikan, Semarang: Universitas Diponegoro.

Latif, Yudi. 2015. Negara Paripurna, Jakarta: PT. Gramedia Pustaka Utama.

Nengsih, Yuni Astuti; Amril Canhrasa; Amrizal., 2019, Nilai-Nilai Religius dalam Novel Penangsang Lukisan Sembilan Cahaya Karya Nassirun Purwokartun, dalam Jurnal Ilmiah Korpus, Vol. 3 No, 2 Agustus 2019.

Pane, Nina (ed). 2015. Mohammad Hatta: Politik, Kebangsaan, Ekonomi (1926-1977), Jakarta: Kompas Gramedia Media Nusantara.

Permata, K.A.W., I.W. Rasna., I.G. Nurjaya., 2014, Analisis Nilai-Nilai Kemanusiaan Novel "Bekisar Merah" Karya Ahmad Tohari dan Kesesuaiannya sebagai Bahan Pembelajaran Sastra, dalam e-jurnal Pendidikan Bahasa dan Sastra Indonesia, Vol. 2 No 1, Bali: Undhiksa.

Ratna, Nyoman Kunta. 2007. Teori, Metode, dan Teknik Penelitian Sastra. Yogyakarta: Pustaka Pelajar.

Rosid, Ayip. 2017. Ikhtisar Sejarah Sastra Indonesia. Bandung: Pustaka Jaya.

Salam, Aprinus. 2003. Identitas dan Nasionalitas dalam Sastra Indonesia:Humaniora. 15 (1): $15-22$

Sawasono, SE. 2014. Prosiding Penguatan, Sinkronisasi, Harmonisasi, Integrasi Pelembagaan dan Pembudayaan Pancasila dalam rangka Memperkokoh Kedaulatan Bangsa. Kebangsaan, Kerakyatan dan Kebudayaan.Hal:69-98

Setiawan, S. 2018. Pascakolonial: Wacana, Teori, dan Aplikasi.Yogyakarta: Gambang Buku Budaya

Sulfikar, Amir. Kompas: Epistomologi Nasionalisme. (Online) http://kompas.com/kompascetak/0411/03/Bentara/1363295.htm, diakses: 24 Oktober 2020

Wulandari, Prisca Kiki dkk. 2017. Membangun Indonesia: Pemberdayaan Pemuda Berwawasan Pancasila, Malang: UB Press.

Yulsafli dan Fusrida, 2018, Nilai-Nilai Nasionalisme dalam Novel Cut Nyak Dhien Karya Skelely Lulofs, dalam Jurnal Humaniora, Vol 2 No. 1 April 2018 hal. 74-87. 